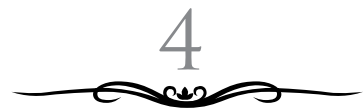

\title{
PENGARUH PERPUSTAKAAN BAGI PENINGKATAN MUTU PENDIDIKAN PERGURUAN TINGGI
}

\author{
Mubasyaroh \\ STAIN Kudus, Jawa Tengah, Indonesia \\ mubasyaroh@gmail.com
}

\begin{abstract}
The library is an elan vital in educational institutions, existence determines the quality of educational institutions including colleges. Like body, the library as the heart, so that the life and death of colleges greatly influenced the healt of the library in this case the quantity and quality. People have to known the library as an integral part of the part of the process of learning and education. The position and function of the library ocucupies a strategic position and role as a facilitator of lifelong learning. The library is an institution managing the collection of papers, printed and recorded works professionally whit a standard system to meet the needs of education, research, conservation and recreation information for pemustaka. In education, the company libraries have a vital role in the learning process, especially in colleges. The library is like the heart of colleges that are the yardsticks, good and bad, healthy or not an education system that is in it. This paper will reveal about several issues related to the presence of libraries in colleges, especially to unveil the role of libraries for improving the quality of higher education.
\end{abstract}

Keywords: Library, Colleges, Heart, Quality. 


\begin{abstract}
Abstrak
Perpustakaan merupakan elan vital dalam lembaga pendidikan, keberadaannya sangat menentukan kualitas dari lembaga pendidikan termasuk di perguruan tinggi. Ibarat tubuh, perpustakaan sebagai jantung, sehingga hidup matinya perguruan tinggi sangat dipengaruhi kesehatan perpustakaan dalam hal ini kuantitas dan kualitasnya. Masyarakat telah mengenal perpustakaan sebagai bagian integral dari proses pembelajaran dan pendidikan. Kedudukan dan fungsi perpustakaan menempati posisi yang strategis dan berperan sebagaifasilitator pembelajaransepanjanghayat.Perpustakaan adalah institusi pengelola koleksi karya tulis, karya cetak dan karya rekam secara professional dengan sistem yang baku guna memenuhi kebutuhan pendidikan, penelitian, pelestarian informasi dan rekreasi bagi para pemustaka. Dalam dunia pendidikan, perpustakaan mempunyai peran vital dalam proses pembelajarannya, terutama di perguruan tinggi. Perpustakaan diibaratkan jantung perguruan tinggi yang menjadi tolak ukur, baik buruk, sehat dan tidaknya suatu sistem pendidikan yang ada di dalamnya. Makalah ini akan mengungkap tentang beberapa hal terkait dengan keberadaan perpustakaan di perguruan tinggi, khususnya akan mengungkap peran perpustakaan bagi peningkatan kualitas perguruan tinggi.
\end{abstract}

Kata Kunci: Perpustakaan, Perguruan Tinggi, Jantung, Kualitas.

\title{
A. Pendahuluan
}

Perpustakaan bukan merupakan hal yang baru di kalangan masyarakat, dibeberapa tempattelah diselenggarakanperpustakaan, seperti sekolah-sekolah, lembaga-lembaga sosial khususnya perguruan tinggi. Perpustakaan tidak hanya sebagai tumpukan buku tanpa ada gunanya, tetapi secara prinsip, perpustakaan harus dapat dijadikan atau berfungsi sebagai sumber infromasi bagi setiap yang membutuhkannya. Dalam dunia pendidikan, perpustakaan mempunyai peran vital dalam proses pembelajaran, terutama di lembaga pendidikan. 
Berdasarkan UU N0. 43 tahun 2007 tentang perpustakaan, pasal 3 menjelaskan bahwa fungsi perpustakaan sebagai wahana pendidikan, penelitian, pelestarian, informasi dan rekreasi untuk meningkatkan kecerdasan dan keberdayaan bangsa. Ironisnya, pemahaman seperti itu belum mengakar kuat di masyarakat. Akibatnya, perpustakaan masih saja dijadikan sebagai gudang buku dan penelngkap akreditasi belaka, bahkan lebih parah dijadikan sebagai tempat pembuangan orang yang bermasalah. ${ }^{1}$

Terlepas dari pro dan kontra tentang perpustakaan, disadari atau tidak, perpustakaan bisa menjadi solusi bagi kegiatan belajar mengajar di perguruan tinggi. Dalam perpustakaan, para mahasiswa dapat memperoleh pengetahuan yang lebih luas dan banyak. Sehingga, keberadaan perpustakaan di perguruan tinggi benar-benar menjadi sarana pembelajaran, dibutuhkan adanya program atau kegiatan yang dilakukan di perguruan tinggi. Salah satu jenis perpustakaan yang paling banyak ditemui di Indonesia adalah perpustakaan perguruan tinggi. Sebagai salah satu jenis perpustakaan, perpustakaan perguruan tinggi sering diibaratkan sebagai jantungnya perguruan tinggi (the heart of university).

Sebagai jantungnya perguruan tinggi, keberadaannya merupakan elan vital dan tidak dapat dikesampingkan, sehingga maju mundurnya perguruan tinggi sangat dipengaruhi oleh kualitas perpustakaan yang dapat ditinjau dari jumlah referensi/buku yang tersedia, pelayanan maupun ketersediaan fasilitas lain yang ada di perpustkaan termasuk di dalamnya ruang baca dan penataan koleksinya.Tulisan ini akan menjelaskan persoalan diatas.

\section{B. Pembahasan}

\section{Konsepsi dan Fungsi Perpustakaan}

Keberadaan perpustakaan di beberapa lembaga memiliki peran dan fungsi yang berbeda, dari tingkat pusat maupun daerah serta lembaga pemerintah dan swasta, terdapat berbagai jenis

${ }^{1}$ Moh Mursyid, Be a Writer libraria; Strategi Jitu Menjadi Penulis Kreatif bagi Pustakawan, (Lembaga Ladang Kata, Yogyakarta, 2015), hlm. 99. 
perpustakaan yang telah dikenal oleh masyarakat luas diantaranya adalah perpustakaan nasional, perpustakaan daerah, perpustakaan perguruan tinggi, perpustakaan sekolah, perpustakaan khusus, dan perpustakaan masjid atau tempat ibadah lainnya. Namun demikian pemanfaatannya ternyata masih jauh dari harapan. Perpustakaan sekolah misalnya masih dipandang sebelah mata oleh berbagai pihak. Padahal perpustakaan sekolah memiliki posisi yang strategis sebagai mitra proses transfer ilmu pengetahuan antara siswa dan guru disekolah. Seringkali perpustakaan sekolah hanya dijadikan "pemanis pendidikan" dengan slogan "perpustakaan adalah jantungnya pendidikan" tanpa adanya tindakan implementasi hakikat jantung pendidikan yang semestinya.

Sebelum membahas peran dan fungsi perpustakaan di lembaga pendidikan, berikut penulis sapaikan definisi perpustakaan. Yaitu suatu unit kerja dari suatu badan atau lembaga tertentu yang mengelola bahan-bahan pustaka, baik berupa bukubuku maupun bukan berupa buku (non book material) yang diatur secara sistematis menurut aturan tertentu sehingga dapat digunakan sebagai sumber informasi oleh setiap pemakainya. ${ }^{2}$

Memang pengertian perpustakaan terkadang rancu dengan istilah - istilah pustaka, pustakawan, kepustakawanan, dan ilmu perpustakaan. Secara harfiah, perpustakaan sendiri masih dipahami sebagai sebuah bangunan fisik tempat menyimpan buku - buku atau bahan pustaka. Untuk itu, pada pembahasan kali ini akan dikupas secara mendalam tentang pengantar umum perpustakaan yang meliputi : pengertian perpustakaan, maksud dan tujuan pendirian perpustakaan, jenis - jenis perpustakaan, peranan, tugas, dan funsi perpustakaan, aktifitas pokok perpustakaan, dan perpustakaan sebagai disiplin ilmu.

Pada sisi lain, perpustakaan diartikan sebuah ruangan atau gedung yang digunakan untuk menyimpan buku dan terbitan

${ }^{2}$ Ibrahim Bafadal, Pengelolaan Perpustakaan Sekolah, (Jakarta, Bumi Aksara, 2008), hlm. 3. 
lainnya yang biasanya disimpan menurut tata susunan tertentu yang digunakan pembaca bukan untuk dijual. ${ }^{3}$

Smith dkk dalam buku ensiklopedianya berjudul "The Educator's Encyclopedia" menyatakan "school library is a center for leraning"' yang artinya perpustakaan sekolah merupakan sumber belajarpada setiap. Hal ini memang benar, sebab kegiatan yang paling nampak dalam setiap kunjungan para peserta didik adalah belajar. Begitu juga yang terjadi pada perpustakaan di perguruan tinggi, bahwa mahasiswa mengunjungi perpustakaan biasanya terkait dengan tugas mata kuliah maupun tidak. Sehingga ada ketergantungan mahasiswa terhadap perpustakaan dalam rangka memenuhi kebutuhan referensi serta informasi lainnya.

Ada beberapa fungsi perpustakaan, diantaranya menurut Bafadal ${ }^{4}$ :

1. Fungsi Edukatif

Dalam perpustakaan disediakan buku-buku fiksi maupun non fiksi. Adanya buku-buku tersebut dapat membiasakan muris-muris belajar mandiri tanpa bimbingan guru, baik secara indivual maupun kelompok. Perpustakaan merupakan sarana pendidikan, artinya perpustakaan merupakan tempat belajar di luar bangku sekolah maupun tempat belajar di lingkungan lembaga pendidikan.

2. Fungsi Informatif

Perpustakaan yang sudah maju tidak hanya menyediakan bahan-bahan pustaka yang berupa bukubuku, tetapi juga menyediakan bahan-bahan yang bukan berupa buku (non book material) seperi majalah, bulletin, surat kabar, pamflet, guntingan artikel, peta, bahkan dilengkapi juga dengan alat-alat pandang dengar seperti overhead projector, slide projector, filmstrip projector, televisi, video, tape recorder dan sebagainya.

${ }^{3}$ Sulistyo-Basuki, Pengantar Ilmu Perpustakaan, (Jakarta: Gramedia Pustaka Utama, 1991), hlm. 7

${ }^{4}$ Ibrahim Bafadal, Op. Cit., hlm. 6-8 
Disamping itu, perpustakaan juga berfungsi sebagai tempat menyimpan karya manusia, khususnya karya cetak, seperti buku, majalah dan sejenisnya serat karya rekaman seperti kaset, piringan hitam, dan sejenisnya. Dalam kaitannya dengan fungsi simpan, perpustakaan bertugas menyimpan khasanah budaya hasil pemikiran masyarakat.

3. Fungsi Tanggung Jawab dan Administrasi

Fungsi ini tampak pada kegiatan sehari-hari di perpustakaan sekolah, dimana setiap peminjaman dan pengembalian buku selalu dicatat oleh guru pustakawan. Setiap pengunjung perpustakaan harus dicatat oleh petugas perpustakaan. Bagi pengunjung harus menunjukkan kartu anggota, atau kartu identitas yang lain, tidak memperbolehkan membawa tas, tidak boleh mengganggu teman-temannya yang sedang belajar. Selain itu, apabila terlambat mengembalikan maupun menghilangkan buku atau koleksi perpustakaan akan didenda atau harus menggantinya.

4. Fungsi Riset

Sebagaimana dijelaskan sebelumnya, bahwa perpustakaan menyimpan koleksi dengan berbagai bentuk, baik buku, majalah maupun koleksi yang lain. Adanya bahan pustaka yang lengkap tersebut memberikan peluang bagi pengguna perpustakaan di perguruan tinggi, baik mahasiswa mapun dosen untuk melakukan penelitian di sisi. Riset atau penelitian dapat dilakukan di perpustakaan terkait dengan penelitian pustaka atau "library research", sehingga keberadaan bahan kajian aka mempermudah peneliti mengakses informasi bahan bacaan sebagai sumber maupun bahan riset yang dilakukan. Dengan demikian perpustakaan memberikan kontribusinya dalam tri dharma perguruan tinggi dalam bidang pendidikan dan penelitian.

5. Fungsi Rekreatif

Fungsi rekreatif perpustakaan menunjukkan, bahwa 
perpustakaan dapat dijadikan sebagai tempat mengisi waktu luang seperti pada waktu istirahat, sehingga setelah mengikuti perkualiahan atau pembelajaran mereka menuju ke perpustakaan untuk refreshing dengan membaca buku-buku ringan yang tidak terkait dengan materi pembelajaran, misalnya buku cerita, novel, roman, majalah, surat kabar dan sebagainya.

Kelima fungsi inilah yang akan dijadikan bahan pertimbangan bagi pengelola untuk meningkatkan layanan perpustakaan bagi para pengguna (user). Diantaranya adalah meningkatkan koleksi, layanan, sarana prasarana dengan mamanfaatkan teknologi terkini, serta menyediakan layanan dan akse ke sumber informasi bagi pengunjung informasi.

\section{Undang-undang tentang Perpustakaan}

Guna memperoleh kejelasan tentang posisi perpustakaan di Perguruan Tinggi, berikut penulis sampaikan ringkasan tentang Undang-undang keperpustakaan ${ }^{5}$

1. Pendahuluan Perpustakaan berfungsi untuk mendukung Sistem Pendidikan Nasional sebagaimana diatur dengan Undang-undang Nomor 20 Tahun 2003 tentang Sistem Pendidikan Nasional (SISDIKNAS).

Perpustakaan merupakan pusat sumber infor-masi, ilmu pengetahuan, teknologi, kesenian, dan kebudayaan. Selain itu, perpustakaan sebagai bagian dari masyarakat dunia ikut serta membangun masyarakat informasi berbasis teknologi informasi dan komunikasi sebagaimana dituangkan dalam Deklarasi World Summit of Information Society-WSIS, 12 Desember 2003.

Hal ini pun dapat terwujud jika pustakawan memiliki

5 Rismayeti, Jurnal Ilmu Budaya Vol. 9 No. 2 Februari 2013 dengan judul Perpustakaan Perguruan Tinggi: Pedoman, Pengelolaan dan Standardisasi, diakses dari http://bpsdmkp.kkp.go.id/ apps/perpustakaan/ ?q=node $/ 74$ 
kompetensi. Salah satu jenis perpustakaan yang paling banyak ditemui di Indonesia adalah perpustakaan perguruan tinggi. Sebagai salah satu jenis perpustakaan, perpustakaan perguruan tinggi sering diibaratkan sebagai jantungnya perguruan tinggi (the heart of university). Oleh karena itu, agar dapat mewujudkan perpustakaan yang menjadi inti dari sebuah perguruan tinggi, maka perlu adanya pemahaman menyeluruh mengenai apa dan bagaimana pengelolaan perpustakaan perguruan tinggi tersebut.

2. Perpustakaan Perguruan Tinggi:Sebuah penjelasandefinitif. Perpustakaan diartikan sebuah ruangan atau gedung yang digunakan untuk penyimpan buku dan terbitan lainnya yang biasanya disimpan menurut tata susunan tertentu yang digunakan pembaca bukan untuk di jual.

Defenisi lain mengatakan, "Perpustakaan adalah unit kerja yang mengelola koleksi dan informasi untuk dipergunakan masyarakat pemakai." Menurut IFLA (International Federation of Library Associations and Institutions) dalam Syafruddin, perpustakaan merupakan kumpulan bahan tercetak dan non cetak dan atau sumber informasi dalam komputer yang tersusun secara sistematis untuk kepentingan pengguna." Dari beberapa pengertian di atas dapat dipahami bahwa pengertian perpustakaan secara umum adalah suatu unit kerja yang berupa tempat mengumpulkan, menyimpan dan memelihara koleksi pustaka baik buku-buku ataupun bacaan lainnya yang diatur, diorganisasikan dan diadministrasikan dengan cara tertentu untuk memberi kemudahan dan digunakan secara kontinu oleh penggunanya sebagai informasi. Oleh karena itu perpustakaan mempunyai fungsi utama melestarikan hasil budaya umat manusia tersebut, khususnya yang berbentuk dokumen karya cetak dan karya rekam lainnya, serta menyampaikan gagasan, pemikiran, pengalaman, dan pengetahuan 
umat manusia itu kepada generasi-generasi selanjutnya. ${ }^{6}$ Terkait dengan perpustakaan perguruan tinggi sebagaimana diatur dalam Undang-undang Nomor 43 Tahun 2007 Pasal 24, bahwa: (1) Setiap perguruan tinggi menyelenggarakan perpustakaan yang memenuhi standar nasional perpustakaan dengan memperhatikan Standar Nasional Pendidikan.(2) Perpustakaan sebagaimana dimaksud pada ayat (1) memiliki koleksi, baik jumlah judul maupun jumlah eksemplarnya, yang mencukupi untuk mendukung pelaksanaan pendidikan, penelitian, dan pengabdian kepada masyarakat, (3) Perpustakaan perguruan tinggi mengembangkan layanan perpustakaan berbasis teknologi informasi dan komunikasi, (4) Setiap perguruan tinggi mengalokasikan dana untuk pengembangan perpustakaan sesuai dengan peraturan perundang-undangan guna memenuhi standar nasional pendidikan dan standar nasional perpustakaan. Keberadaan perpustakaan perguruan tinggi dipandang sangat strategis dalam pengembangan ilmu pengetahuan dan teknologi. Sutarno mendefenisikan sebagai berikut: Perpustakaan Perguruan Tinggi merupakan perpustakaan yang berada dalam suatu perguruan tinggi dan yang sederajat yang berfungsi mencapai Tri Dharma Perguruan Tinggi, sedangkan penggunanya adalah seluruh civitas akademika.

3. Tujuan, Fungsi dan Tugas Perpustakaan Perguruan Tinggi Perpustakaan perguruan tinggi sering dimaknai sebagai pusat penelitian karena banyak menyediakan informasi yang berkaitan dengan sarana pendukung dalam proses penelitian. Adapun sisi lain tujuannya sebagai Unit Pelaksana Teknis (UPT) dari suatu perguruan tinggi yang bersama-sama dengan unit lain melakukan kegiatannya sehingga terlaksana penyelenggaraan dalam membantu lembaga induknya untuk melaksanakan Tri Dharma

6 ibid., hlm 43. 
Perguruan Tinggi. Menurut Sulistyo Basuki, tujuan penyelenggaraan perpustakaan perguruan tinggi adalah:

Untuk memenuhi keperluan informasi masyarakat perguruan tinggi, lazimnya staf pengajar dan mahasiswa sering pula mencakup tenaga administrasi perguruan tinggi

1. Menyediakan bahan pustaka rujukan (reference) pada semua tingkat akademis, artinya mulai dari mahasiswa tahun pertama hingga ke mahasiswa program pasca sarjana dan pengajar

2. Menyediakan ruang belajar untuk pemakai perpustakaan

3. Menyediakan jasa peminjaman yang tepat guna bagi berbagai jenis pemakai

4. Menyediakan jenis informasi aktif yang tidak hanya terbatas pada lingkungan perguruan tinggi tetapi juga lembaga induknya.

Dari uraian di atas dapat dipahami bahwa tujuan dari perpustakaan perguruan tinggi adalah sebagai penyedia jasa pelayanan informasi yang meliputi pengumpulan, pelestarian, pengolahan, pemanfaatan dan penyebaran informasi sehingga dapat dimanfaatkan pengguna, penyediaan fasilitas yang mendukung dalam memenuhi kebutuhan informasi civitas akademika, pemberian berbagai jasa informasi serta pengembangan mutu perguruan tinggi pada tempatnya bernaung. Untuk mencapai tujuan yang sempurna harus didukung juga dengan fungsinya. Adapun fungsi perpustakaan perguruan tinggi adalah:

1. Fungsi Edukasi; perpustakaan merupakan sumber belajar para civitas akademika, oleh karena itu perpustakaan harus mampu mendukung pencapaian tujuan menyediakan bahan pembelajaran setiap program studi, koleksi tentang strategi belajar mengajar dan materi pendukung pelaksana evaluasi pembelajaran.

2. Fungsi Informasi; perpustakaan merupakan sumber 
informasi yang mudah diakses oleh pencari dan pengguna informasi.

3. Fungsi Riset; perpustakaan mempersiapkan bahan-bahan primer dan sekunder yang paling mutakhir sebagai bahan untuk melakukan penelitian dan pengkajian ilmu pengetahuan, teknologi, dan seni.

4. Fungsi Rekreasi; perpustakaan harus menyediakan koleksi rekreatif yang bermakna untuk membangun dan mengembangkan kreativitas, minat dan daya inovasi pengguna perpustakaan.

5. Fungsi Publikasi; perpustakaan selayaknya juga membantu melakukan publikasi karya yang dihasilkan oleh warga perguruan tingginya yakni civitas akademika dan staf non-akademik.

6. Fungsi Deposit; perpustakaan menjadi pusat deposit untuk seluruh karya dan pengetahuan yang dihasilkan oleh warga perguruan tingginya. Fungsi Interpretasi; perpustakaan sudah seharusnya melakukan kajian dan memberikan nilai tambah terhadap sumber-sumber informasi yang dimilikinya untuk membantu pengguna dalam melakukan dharmanya.

Daripemaparandiatasdapatdisimpulkanbahwafungsi sebuah perpustakaan perguruan tinggi adalah sebagai sarana penyediaan fasilitas pengajaran dan penelitian untuk memenuhi kebutuhan informasi yang dibutuhkan civitas akademikanya yang memiliki kualitas koleksi yang memadai dan sesuai terhadap kebutuhan sehingga menimbulkan kepuasan akan kebutuhan informasi para pengguna.

4. Unsur-unsur Pendirian Perpustakaan Perguruan Tinggi Untuk dapat didirikannya Perpustakaan Perguruan Tinggi, ada beberapa hal yang perlu diperhatikan, yaitu landasan hukum berdiri Perpustakaan Perguruan Tinggi, struktur organisasi dan sumber daya manusia. Landasan Hukum. Landasan Hukum merupakan dasar atau pedoman serta peraturan dalam pendirian perpustakaan 
di Perguruan Tinggi dan sebagai persyaratan berdirinya perpustakaan antara lain:

a. Undang-undang no 2 tahun 1989 tentang Sistem Pendidikan Nasional

b. Undang-undang No. 43 tahun 2007 tentang Perpustakaan,

c. Peraturan Pemerintah no. 30 tahun 1990 tentang Pendidikan Tinggi,

d. Keputusan Menteri Pendidikan dan Kebudayaan no. 0686/U/1991 tentang Pedoman Pendirian Perguruan Tinggi

e. Surat Keputusan Dirjen Dikti no. 162/1967 tentang Persyaratan Minimal Perguruan Tinggi

f. Surat Edaran Bersama Menteri Pendidikan dan Kebudayaan serta Kepala Badan Adminitrasi Kepegawaian Negara no. 53649/MPK/1988, dan No. 15?SE/1988,

g. Surat Keputusan Menteri Negara Pendayagunaan Aparatur Nagara Tentang Angka Kredit bagi Jabatan Pustakawan No. 18/MENPAN/1988

h. Surat Keputusan MENPAN No. 33 Tahun 1998,

i. Revisi Keputusan MENPAN no. 132/KEP/M.PAN/ 12/2002. Tentang Jabatan Fungsional Pustakawan dan Angka Kreditnya.

1. Struktur Organisasi

Berdasarkan Peraturan Pemerintah No. 30 Tahun 1990 pasal 34 PPT sebagai unit pelaksana teknis merupakan salah satu unsur penunjang sebagai kelengkapan bagi pendidikan, penelitian dan pengabdian kepada masyarakat, kedudukannya di luar lingkup fakultas dan bertanggungjawab langsung kepada rektor/ ketua/direktur.

Struktur organisasi PPT dapat dikategorikan dalam dua bentuk yaitu: (1) Struktur organisasi Makro artinya kedudukan PPT dalam struktur lembaga / institusi, dan (2)Struktur organisasi Mikro artinya kedudukan /struktur 
intern unit perpustakaan dengan segala bagian dan unit kerja /kegiatannya.

Untuk struktur organisasi mikro ini menimal mencakup 3 bagian yaitu : 1) bagian pelayanan teknis; 2) bagian pelayanan pengguna / pemustaka dan 3) bagian tata usaha. Sesuai dengan perkembangan jenis dan bentuk layanan serta peningkatan pemanfaatan teknologi informasi maka struktur organisasi dapat dikembangkan sesuai dengan kebutuhan masing-masing. 2. Sumber Daya Manusia

Di perpustakaan jenis apapun sumber daya manusia merupakan unsur yang sangat penting karena merupakan ujung tombak dan ujung kekuatan proses pemberian dan penerimaan informasi dari sumber informasi dalam hal ini pengelola perpustakaan dan pemanfaat informasi atau pengguna (pemustaka)

a. Pemustaka / Pengguna/ User

Pada dasarnya perpustakaan tidak akan ada artinya apabila tidak ada pengunjung yang memanfaatkan atau menggunakan bahan pustaka/koleksinya yaitu user/ pemustaka. Pemustaka adalah pengguna perpustakaan yaitu perseorangan, kelompok orang, masyarakat, atau lembaga yang memanfaatkan fasilitas layanan perpustakaan. Jumlah personal yang datang ke perpustakaan merupakan tolok ukur keberhasilan suatu perpustakaan. Terdapat dua katagori pemustaka yaitu potential user (adalah jumlah civitas akademika yang ada pada PT) dan actual users (merupakan civitas akademika yangmemanfaatkan perpustakaan/pemustakayang datang ke perpustakaan/pemustaka riil). Agar dapat memberikan layanan yang optimal dan memuaskan pemustaka maka pustakawan harus memperhatikan beberapa hal antara lain: (1) Bidang Studi, (2) Jenjang Pendidikan, (3) Status, (4) Usia, (5)Jenis Kelamin, (6) Sosial Ekonomi, dan (7) Sosial Budaya.

b. Tenaga Pengelola Perpustakaan / Pustakawan 
Bab VIII Pasal 29 (1) UU No 43 tahun 2007 menyatakan bahwa tenaga perpustakaan terdiri atas pustakawan dan tenaga teknis perpustakaan. (2) pustakawan sebagaimana dimaksud pada ayat (1) harus memenuhi kualifikasi sesuai dengan standar nasional perpustakaan. (3) tugas tenaga teknis perpustakaan sebagaimana dimaksud ayat (1) dapat dirangkap oleh pustakawan sesuai dengan kondisi perpustakaan yang bersangkutan. (4) ketentuan mengenai tugas, tanggungjawab, pengangkatan, pembinaan, promosi, pemindahan tugas, dan pemberhentian tenaga yang berstatus pegawai negeri sipil dilakukan sesuai dengan peraturan perundangundangan. (5) ketentuan mengenai tugas, tanggungjawab, pengangkatan, pembinaan, promosi, pemindahan tugas, dan pemberhentian tenaga yang berstatus non pegawai negeri sipil dilakukan sesuai dengan peraturan yang ditetapkan oleh penyelenggara perpustakaan yang bersangkutan. Dalam Undang-undang Nomor 43 tahun 2007 pasal 1 (8) disebutkan bahwa Pustakawan adalah seseorang yang memiliki kompetensi yang diperoleh melalui pendidikan dan atau pelatihan kepustakawanan serta mempunyai tugas dan tanggungjawab untuk melaksanakan pengelolaan dan pelayanan perpustakaan. Dalam dunia pendidikan tinggi dengan masyarakat civitas akademika yang dilayani, maka tenaga pengelola perpustakaan harus memiliki kriteria tertentu. Pengelola perpustakaan (pustakawan) harus dapat merubah dirinya agar bisa mengubah image dan paradigma stereotype pustakawan seperti tersebut di atas. Terdapat beberapa hal yang harus dimiliki oleh para pengelola PPT pada era global antara lain : (1) Memiliki Pendidikan dan Ketrampilan Tentang Kepustakawanan, (2) Memiliki Ketrampilan Pemanfaatan Teknologi Informasi, (3) Memiliki Ketrampilan Bahasa, (4) Mengetahui Kebutuhan Pemustaka, dan (5) Sense of Media. 
5. Koleksi / Bahan Pustaka

Keputusan MENDIKBUD Republik Indonesia No. 0696/ U/1991 bab II Pasal 11 menetapkan persyaratan minimal koleksi PPT untuk program Diploma dan S1: Memiliki 1 (satu) judul pustaka untuk setiap mata kuliah keahlian dasar (MKDK), Memiliki dua judul pustaka untuk tiap mata kuliah keahlian (MKK), Berlangganan sekurangkurangnya satu judul jurnal ilmiah untuk setiap Program studi, Jumlah pustaka sekurang-kurangnya 10\% dari jumlah mahasiswa dengan memperhatikan komposisi subyek pustaka.Sedangkan untuk Program Pascasarjana dan Sp 1: (1) Memiliki 500 judul pustaka untuk setiap program studi, dan (2) berlangganan sekurang-kurangnya 2 (dua) jurnal ilmiah untuk setiap program studi.

6. Gedung / Ruang /Peralatan / Fasilitas

Gedung atau ruang perpustakaan merupakan tempat khusus yang dirancang sesuai dengan fungsi perpustakaan sehingga berbeda dengan perancangan gedung atau ruang perkantoran umum. Untuk itu dalam merencanakan gedung atau ruangan sebaiknya dilakukan oleh pengelola perpustakaan. Letak gedung atau ruang sebaiknya di lokasi yang strategis dan aksesebel (mudah dijangkau alat transportasi umum). Bab IX pasal 38 UU No. 43 tahun 2007 menyebutkan bahwa: (1) Setiap penyelenggara Perpustakaan menyediakan sarana dan prasarana sesuai dengan standar nasional perpustakaan. (2) Sarana dan prasarana sebagaimana dimaksud pada ayat (1) dimanfaatkan dan dikembangkan sesuai dengan kemajuan teknologi informasi dan komunikasi. Agar dapat memberikan layanan yang optimal, nyaman dan menyenangkan, maka fasilitas peralatan komunikasi, teknologi informasi serta pemberian rambu-rambu Perpustakaan dapat disesuaikan dengan kebutuhan dan pengembangan layanan fasilitas Perpustakaan dengan perencanaan 
yang matang; menyediakan jaminan dan ruang yang cukup, suasana yang kondusif untuk belajar dan riset dengan kondisi lingkungan yang cocok untuk pelayanan perpustakaan, anggota, sumber, dan berbagai koleksi, sehingga perlengkapan perpustakaan haruslah memadai dan fungsional.

7. Manajemen

Manajemen adalah kebutuhan pokok sebagai salah satu syarat pendirian perpustakaan, karena minimal berfungsi sebagai perencana (planning), pengorganisaasian (organizing), pengawasan (controlling). Undang-undang Nomor 43 tahun 2007 pasal 15 ayat 3 menyebutkan: Pembentukan perpustakaan sebagaimana dimaksud pada ayat 2 paling sedikit memenuhi syarat: Memiliki koleksi perpustakaan, Memiliki tenaga perpustakaan, Memiliki sarana dan prasarana perpustakaan, Memiliki sumber pendanaan; dan Memberitahukan keberadaannya ke perpustakaan nasional.

Agar yang dimiliki seperti tersebut di atas dapat dioptimalkan maka perlu melaksanakan manajemen yang baik dan terencana dalam melaksanakan peraturan yang berlaku demi lancarnya dan tercapainya tujuan PT dalam memberikan layanan penunjang kepada civitas akademika untuk keberhasilan proses pembelajaran, penelitian ataupun pengabdian kepada masyarakat. Hal-hal yang harus dilakukan adalah dengan mengelola, mengolah, mengatur koleksi, SDM, fasilitas dan dana. Selain itu juga membuat laporan, memantau dan mengukur kinerja serta mengevaluasi dan membuat program kerja secara berkesinambungan dengan analisis SWOT.

\section{Dana / Anggaran}

Bab 10 pasal 39 (1) menjelaskan Pendanaan perpustakaan menjadi tanggung jawab penyelenggara perpustakaan. (2) Pemerintah dan pemerintah daerah mengalokasikan anggaran perpustakaan dalam anggaran pendapatan dan 
belanja negara (APBN) dan anggaran pendapatan dan belanja daerah (APBD). Untuk pelaksanaannya tergantung dari masing-masing lembaga sehingga perolehan dana dapat dijabarkan berasal dari: APBN, APBD/DIPA, APB sendiri (intern), Yayasan, Donatur, Sponsor, Masyarakat. Lebih lanjut pada pasal 40 disebutkan bahwa:

1. Pendanaan perpustakaan didasarkan pada prinsip kecukupan dan berkelanjutan.

2. Pendanaan perpustakaan bersumber dari:

(a) anggaran pendapatan dan belanja negara dan/atau anggaran pendapatan dan belanja daerah;

(b) sebagian anggaran pendidikan;

(c) sumbangan masyarakat yang tidak mengikat;

(d) kerja sama yang saling menguntungkan;

(e) bantuan luar negeri yang tidak mengikat;

(f) hasil usaha jasa perpustakaan, dan/atau

(g) sumber lain yang sah berdasarkan ketentuan peraturan perundang-undangan dan dalam pengelolaan dana perpustakaan dilakukan secara efisien, berkeadilan, terbuka, terukur, dan bertanggung jawab.(Pasal 41).

9. Pelayanan Teknis dan Pelayanan Perpustakaan Pelayanan perpustakaanapabiladitinjau darikegiatannya maka terdapat dua jenis layanan di perpustakaan yaitu layanan teknis yang meliputi pengolahan dan pelayanan perpustakaan sebagai layanan pengguna. Sedangkan apabila ditinjau dari sistemnya terdapat 3 jenis layanan yaitu: (1) open access; (2) close access; (3) mixed services. Dalam kegiatan pelayanan perpustakan terdapat berbagai jenis layanan yang diberikan kepada pemustaka tergantung dari kebutuhan pemustaka dan disesuaikan dengan program studi yang ada, layanan tersebut antara lain : Layanan Sirkulasi; Layanan Rujukan; Layanan Serial/ Periodical; Layanan A, AV dan AVA; Jasa Kesiagaan Informasi; Penelusuran Pustaka; Layanan 
Foto Copy; Layanan Pinjam antar Perpustakaan; Pembuatan Abstrak, Indeks dan Bibliografi; Layanan Terjemahan; Layanan Buku Tandon; Penyediaan Fasilitas; dll. Dalam Undang-undang Nomor 43 Tahun 2007 pasal 14 disebutkan bahwa:

1. Layanan perpustakaan dilakukan secara prima dan berorientasi bagi kepentingan pemustaka,

2. Setiap perpustakaan menerapkan tata cara layanan perpustakaan berdasarkan standar nasional perpustakaan,

3. Setiap perpustakaan mengembangkan layanan perpustakaan sesuai dengan kemajuan teknologi informasi dan komunikasi.,

4. Layanan perpustakaan sebagaimana dimaksud pada ayat (1) dikembangkan melalui pemanfaatan sumber daya perpustakaan untuk memenuhi kebutuhan pemustaka,

5. Layanan perpustakaan diselenggarakan sesuai dengan standar nasional perpustakaan untuk mengoptimalkan pelayanan kepada pemustaka,

6. Layanan perpustakaan terpadu diwujudkan melalui kerja sama antar perpustakaan, dan,

7. Layanan perpustakaan secara terpadu sebagaimana dimaksud pada tersebut (6) dilaksanakan melalui jejaring telematika. ${ }^{7}$

10. Kerjasama

Seperti diketahui bersama bahwa perkembangan hasil karya rekam dan tulis serta meningkatnya kebutuhan masyarakat, membutuhkan sarana penyedia informasi yaitu perpustakaan. Namun demikian disadari bersama bahwa tidak satupun perpustakaan yang mampu memberikan pelayanan terhadap semua kebutuhan pemustaka. Sementara pada sisi lain, masalah harga

7 https://pustamik.wordpress.com/2010/07/05/review-uu-ri-no-43tahun-2007-tentang-perpustakaan/ diakses pada 12 Maret 2016 
buku serta terbatasnya tenaga kepustakawanan, menjadi tantangan yang harus dicari solusinya yang memerlukan kerjasama yang baik dengan sesama bidang studi atau bidang lain.

11. Simpulan

Perpustakaan Perguruan Tinggi merupakan Unit Pelayanan Teknis (UPT) perguruan tinggi, yang bersamasama dengan unit lain turut melaksanakan Tri Dharma Perguruan Tinggi dengan cara memilih, menghimpun, mengolah, merawat serta melayani sumber informasi kepada lembaga induknya pada khususnya dan masyarakat akademis pada umumnya. Tujuan dari perpustakaan perguruan tinggi adalah sebagai penyedia jasa pelayanan informasi yang meliputi pengumpulan, pelestarian, pengolahan, pemanfaatan dan penyebaran informasi sehingga dapat dimanfaatkan pengguna, menyediakan fasilitas yang mendukung dalam memenuhi kebutuhan informasi civitas akademika, pemberian berbagai jasa informasi serta pengembangan mutu perguruan tinggi pada tempatnya bernaung.

Dalam pencapaian tujuan yang sempurna harus didukung juga dengan fungsinya. Selain itu, untuk mewujudkan Perpustakaan Perguruan Tinggi yang berkualitas sesuai dengan amanat Undang-undang Nomor 43 Tahun 2007 tentang Perpustakaan, faktor Sumber Daya Manusia/ Pemustaka perlu mendapat perhatian yang serius, dimana para pengelola perpustakaan mulai dari pimpinan, staf dan karyawan di Perpustakaan hendaknya diserahkan kepada tenaga ahli yang memiliki latar belakang keilmuwan di bidang perpustakaan agar pengembangan perpustakaan termasuk pengembangan koleksi benar-benar sesuai dengan tujuan perpustakaan Perguruan Tinggi. ${ }^{8}$

Undang-undang perpustakaan memiliki peran penting

8 http://bpsdmkp.kkp.go.id/apps/perpustakaan/?q=node/74 diakses pada 1 April 2016 
dalam penyelenggaraan dan pengembangan perpustakaan di Indonesia. Selain menjadi sumber hukum, UU ini juga dijadikan sebagai acuan dalam penyelenggaraan dan pengembangan perpustakaan di Indonesia. Dengan lahirnya UU ini juga pekerjaan sebagai pustakawan menjadi semakin dihargai. Bukan lagi dianggap sebagai "pegawai buangan". Terlepas dari kekurangan yang masih ada dalam UU ini dan kurangnya sosialisasi dari pemerintah, kita wajib menjalankan amanah yang ada di UU ini sebagaimana dalam UUD 1945 untuk mencerdaskan anak bangsa.

Semua lembaga penyelenggara perpustakaan yang tidak melaksanakan ketentuan sebagaimana yang diatur oleh undang-undang ini dikenakan sanksi administratif. Sanksi administratif diatur lebih lanjut dengan peraturan pemerintah. Semua peraturan undang-undang yang diperlukan untuk melaksanakan undang-undang tersebut harus diselesaikan paling lambat dua tahun terhitung sejak berlakunya undang-undang ini.

\section{Tata Kerja Perpustakaan Perguruan Tinggi}

Pada uraian sebelumnya telah dijelaskan beberapa fungsi perpustakaan. Akan tetapi perlu dijelaskan di sini bahwa berfungsi tidaknya perpustakaan di perguruan tinggi banyak tergantung peda penataan kerjanya. Memang harus diakui, bahwa ruang, buku-buku dan perlengkapan lainnya berpengaruh terhadap keberhasilan penyelenggaraan perpustakaan. Semua akan bermakna jika perpustakaan ditata dan dikelola dengan sebaik-baiknya. Sehingga, penyelenggaraan perpustakaan dapat menunjang pelaksanaan proses belajar mengajar, maka perlu adanya penataan kerja atau pengelolaan perpustakaan.

Secara definitif, pengelolaan perpustkaan berarti segenap usaha mengkoordinasikan segala kegiatan yang berhubungan dengan penyelenggaraan perpustakaan. Usaha pengkoordinasian tersebutbiasanya diwadahi dalam struktur organisasi perpustakaan. Struktur organisasi harus mampu menunjukkan hubungan antara 
pejabat dan bidang kerja yang satu dengan yang lainnya sehingga jelas kedudukan, wewenang dan tanggung jawab masing-masing

Diantara struktur tersebut antara lain:

- Pelayanan teknis, meliputi; pengadaan bahan-bahan pustaka , inventarisasi bahan-bahan pustaka, katalogisasi bahanbahan pustaka, pembuatan label buku serta penyusunan buku-buku di lemari atau rak buku yang tersedia.

- Pelayanan pembaca, meliputi; melayani peminjaman bukubuku, melayani pengembalian buku-buku, pemberian bimbingan membaca bagi murid-murid, pembinaan minat baca bagi murid-murid serta bantuan informasi kepada semua pihak yang memerlukannya, khususnya warga sekolah. ${ }^{9}$

Semua lembaga penyelenggara perpustakaan yang tidak melaksanakan ketentuan sebagaimana yang diatur oleh undangundang ini dikenakan sanksi administratif. Sanksi administratif diatur lebih lanjut dengan peraturan pemerintah. Semua peraturan undang-undang yang diperlukan untuk melaksanakan undangundang tersebut harus diselesaikan paling lambat dua tahun terhitung sejak berlakunya undang-undang ini. ${ }^{10}$

\section{Peran Perpustakaan bagi Pengembangan Kulitas Perguruan Tinggi}

Dalam Undang-undang Nomor 20 Tahun 2003 tentang Sistem Pendidikan Nasional pada pasal 55 menyebutkan bahwa salah satu syarat untuk menyelenggarakan Perguruan Tinggi harus memiliki Perpustakaan. Sedangkan Perpustakaan Perguruan Tinggi (PPT) merupakan Unit Pelaksana Teknis (UPT) yang bersama-sama dengan unit lain melaksanakan Tri Dharma Perguruan Tinggi dengan cara menghimpun, memilih, mengolah, merawat serta melayani sumber informasi kepada lembaga induk khususnya dan masyarakat akademis pada umumnya. Adapun

${ }_{9}$ Ibrahim Bafadal, Op.Cit., hlm.11-13

10 http://tonyjheyz.blogspot.co.id/ 2012/05/perpustakaan-sekolahmasa-depan.html 
yang termasuk dalam Perguruan Tinggi meliputi universitas, institut, sekolah tinggi, akademi, politeknik dan atau Perguruan Tinggi lain yang sederajat.

Perpustakaan dipandang sebagai perpaduan antara manusia, tempat/dan informasi, karena antara satu dengan yang lainnya saling ketergantungan. Manusia merupakan pengelola dan pemakainya. Tempat/fasilitas merupakan sarana yang digunakan manusia untuk melakukan "transaksi informasi", sedang informasi dapat berupa buku, jurnal, majalah, koran dan materi lainnya yang merupakan bahan-bahan yang harus disajikan di perpustakaan. Sehingga dengan keterpaduan tadi akan jelas misi yang diemban oleh sebuah perpustakaan, yaitu antara lain turut mencerdaskan bangsa dengan menyediakan informasi yang diperlukan, melestarikan nilai-nilai budaya bangsa dan berkiprah dalam pengembangan ilmu dan teknologi.

G. Edward Evan mengatakan ada empat tipe perpustakaan, yaitu: perpustakaan perguruan tinggi, perpustakaan sekolah, perpustakaan umum, dan perpustakaan khusus. Antara satu perpustakaan dengan perpustakaan yang lainnya akan berbeda. Hal ini tergantung dari jenis perpustakaan yang tentunya dari tipe itu akan mempunyai masyarakat pemakai yang berbeda. Oleh karenanya, koleksinya harus disesuaikan dengan kebutuhan pemakainya. Karena masyarakat pemakainya berbeda, maka sistem pelayanannya pun akan berbeda pula. Tugas tri dharma perguruan tinggi ada tiga yaitu pendidikan dan pengajaran, penelitian dan pengambian kepada masyarakat. Dua tugas utama pendidikan dan pengajaran serta bagian penelitian dalam pelaksanaannya sangat memerlukan keberadaan perpustakaan, terkait dengan referensireferensi yang digunakan, sehingga memeiliki ketergantungan dengan perpustakaan.

Dalam hal ini perpustakaan dapat menjadi solusi bagi keperluan penelitian oleh dosen maupun peneliti lain. Sebagaimana diketahui bahwa pendidikan merupakan salah satu hal yang penting dalam kehidupan seseorang. Pendidikan secara umum mempunyai arti proses kehidupan alam mengembangkab diri 
tiap individu untuk dapat hidup dan melangsungkan kehidupan. Menjadi seorang yang terdidik sanga penting, berbagai macam cara dapat dilakukan untuk mendapatkan ilmu pengetahuan (pendidikan), salah satunya melalui perpustakaan.

Secara umum peran perpustakaan perguruan tinggi adalah memberikan pelayanan informasi yang dibutuhkan oleh penggunanya. Dalam buku Pedoman Umum Penyelenggaraan Perpustakaan Perguruan Tinggi dinyatakan bahwa: Perpustakaan Perguruan Tinggi merupakan Unit Pelayanan Teknis (UPT) perguruan tinggi, yang bersama-sama dengan unit lain turut melaksanakan Tri Dharma Perguruan Tinggi dengan cara memilih, menghimpun, mengolah, merawat serta melayankan sumber informasi kepada lembaga induknya pada khususnya dan masyarakat akademis pada umumnya. Sejalan dengan pernyataan di atas, Sulistyo Basuki menyatakan pendapatnya bahwa Perpustakaan Perguruan Tinggi adalah perpustakaan yang terdapat pada perguruan tinggi, badan bawahannya maupun lembaga yang berafiliasi dengan perguruan tinggi, bertujuan utama membantu perguruan tinggi mencapai tujuannya.

Dalam hal ini, ruang peprustakaan sebagai jantungnya perguruan tinggi harus didesain senyaman dan kondusif mungkin, sehingga memungkinkan para mahasiswa untuk belajar dengan nyaman. Nantinya mahasiswa yang berkunjung ke perpustakaan menjadi kerasan dan nyaman. Desain peprustakaan yang menarik tentu menjadi salah satu motivasi mahasiswa agar termotivasi untuk datang ke perpustakaan. Perpustakaan merupakan lembaga yang menjadi pusat informasi, pusat pembelajaran, pusat kajian, serta pusat pengolahan dan penyimpanan informasi.

Keberadaan perpustakaan sangat berpengaruh bagi kesuksesan proses pembelajaran dalam berbagai jenjang pendidikan mulai dari Sekolah Dasar sampai Perguruan Tinggi. Suatu perpustakaan yang baik dan lengkap dapat menyediakan sebuah informasi yang sesuai dengan kebutuhan para pemakai (user) akan mudah ditemukan secara efektif, dan efisien berkat 
adanya sistem temu kembali informasi (information retrievel tools) yang terorganisir dengan baik. ${ }^{11}$

Sebagai jantungnya perguruan tinggi, perpustakaan memiliki peran yang penting serta besar pengaruhnya terhadap mutu pendidikan. Peran ini menjadi besar karena keberadaan perpustakaan merupakan salah satu sarana dan prasarana untuk mendapatkan ilmu pengetahuan. Untuk mencapai tujuan dan fungsinya dengan baik perpustakaan perguruan tinggi mempunyai tugas yang harus dilaksanakan. Setiap pelaksanaannya, selain tujuan dan fungsinya yang baik maka tugas yang diemban perpustakaan senantiasa berusaha menyediakan setiap kebutuhan pengguna.

Menurut Mursyid, ${ }^{12}$ keberadaan perpustakaan di perguruan tinggi harus dapat benar-benar menjadi sarana pembelajaran, sehingga dibutuhkan adanya sebuah program atau kegiatan yang dilakukan oleh perpustakaan perguruan tinggi. Program tersebut ibarat ruh yang menentukan hidup matinya sebuah perpustakaan. Program tersebut harus berorientasi pada pengembangan minat baca mahasiswa. Hal, dikarenakan indikator keberhasilan sebuah perpustakaan adalah meningkatnya minat baca.

Salah satu prasyarat utama dalam menjalankan program tersebut adalah adanya pustakawan yang bertugas sebagai penggerak yang ada di perpustakaan. Pustakawan haruslah seorang yang mempunyai idealisme tinggi, kreatif, dan berwawasan luas. Bukan mereka yang "bermasalaah" juga bukan mereka yang bekerja demi memenuhi angka sertifikasi dan hanya berorientasi pada gaji semata.

Seorang pustakwan harus mampu menjalin komunikasi yang baik dengan semua pemakai perpustakaan. Hal ini akan dapat menunjang peran perpuastakaan di perguruan tinggi Peran perpustakaan yaitu segala fungsi perpustakaan perguruan tinggi sebagaimana yang disebutkan dalam buku pedoman perpustakaan untuk perguruan tinggi. Adapun tugas (kewajiban) yang harus dilakukan perpustakaan perguruan tinggi adalah mengembangkan

11 Kayaberkah-fisip 12.web.unair.ac.id, dikutip pada 15 April 2016

12 Muh Mursyid,Op.Cit, hlm 100-101 
koleksi, mengolah dan merawat bahan perpustakaan, memberi layanan, serta melaksanakan administrasi perpustakaan. ${ }^{13}$

Berlangsungnya kegiatan di sebuah perpustakaan sangat tergantung dari berbagai unsur yang saling berkaitan sehingga bermanfaat untuk banyak pihak. Koleksi, tenaga, tempat, sistem, dan peralatan bersatu dalam kesepakatan untuk menyajikan informasi sesuai permintaan dengan optimal.

\section{Simpulan}

Keberadaan perpustakaan sangat berpengaruh bagi kesuksesan proses pembelajaran dalam berbagaijenjang pendidikan mulai dari SD (Sekolah Dasar) sampai PT (Perguruan Tinggi). Suatu perpustakaan yang baik dan lengkap dapat menyediakan sebuah informasi yang sesuai dengan kebutuhan para pemakai ( user) akan mudah ditemukan secara efektif, dan efisien berkat adanya sistem temu kembali informasi (information retrievel tools) yang terorganisir dengan baik.

Sangatlah jelas UU Perpustakaan mengatur bentuk layanan perpustakaan yang lebih menitikberatkan pada aspek layanan prima, sumber koleksi, pemustaka, pustakawan serta perangkat teknologi informasi dan komunikasi sebagai komponen utama membentuk perpustakaan sekolah masa depan.

${ }^{13}$ Lebih lanjut lihat Perpustakaan Perguruan Tinggi: Buku Pedoman, 2004:3 atau cermatipada bab sebelumnya tentang undang-undang perpustakaan, sebagaimanadisebutkanperan perpustakaansebagaiberikut:Setiapperpustakaan dapat mempertahankan eksistensinya apabila dapat menjalankan peranannya. Secara umum peran - peran yang dapat dilakukan adalah: a. Menjadi media antara pemakai dengan koleksi sebagai sumber informasi pengetahuan b. Menjadi lembaga pengembangan minat dan budaya membaca serta pembangkit kesadaran pentingnya belajar sepanjang hayat. c. Mengembangkan komunikasi antara pemakai dan atau dengan penyelenggara sehingga tercipta kolaborasi, sharing pengetahuan maupun komunikasi ilmiah lainnya. d. Motivator, mediator dan fasilitator bagi pemakai dalam usaha mencari, memanfaatkan dan mengembangkan ilmu pengetahuan danpengalaman. e. Berperan sebagai agen perubah, pembangunan dan kebudayaan manusia. 
Sebagai jantungnya perguruan tinggi, keberadaannya merupakan elan vital dan tidak dapat dikesampingkan, sehingga maju mundurnya perguruan tinggi sangat dipengaruhi oleh kualitas perpustakaan yang dapat ditinjau dari jumlah referensi/ buku yang tersedia, pelayanan maupun ketersediaan fasilitas lain yang ada di perpustkaan termasuk di dalamnya ruang baca dan penataan koleksinya. 


\section{DAFTAR PUSTAKA}

Bafadal, Ibrahim. Pengelolaan Perpustakaan Sekolah, Bumi Aksara, Jakarta: Bumi Aksara, 2008.

http://bpsdmkp.kkp.go.id/apps/perpustakaan/?q=node/74 diakses pada 1 April 2016.

http://tonyjheyz.blogspot.co.id/2012/05/perpustakaan-sekolahmasa-depan.html

Kayaberkah-fisip 12.web.unair.ac.id, dikutip pada 15 April 2016

Mursyid, Moh. Be a Writer libraria; Strategi Jitu Menjadi Penulis Kreatif bagi Pustakawan, Yogyakarta: Lembaga Ladang Kata, 2015.

Rismayeti, Jurnal Ilmu Budaya Vol. 9 No. 2 Februari 2013 dengan judul Perpustakaan Perguruan Tinggi : Pedoman, Pengelolaan dan Standardisasi, diakses pada 17 Maret 2015

Sulistyo, Basuki. Pengantar Ilmu Perpustakaan, Jakarta: Gramedia Pustaka Utama, 1991.

Supriyadi, Pengantar Pedoman Penyelenggaraan Perpustakaan Sekolah, Malang: tp. 1982.

Trimo, Soejono. Pedoman Pelaksanaan Perpustakaan, Bandung: CV Remaja Karya, 1985. 
Halaman ini bukan sengaja dikosongkan 